\title{
Slaughter weight rather than sex affects carcass cuts and tissue composition of Bisaro pigs
}

\author{
Javier Álvarez-Rodríguez ${ }^{\mathrm{a}}$, Alfredo Teixeira ${ }^{\mathrm{b}, *}$ \\ ${ }^{a}$ Universitat de Lleida, Departament de Ciència Animal, Avda. Rovira Roure, 191, 25198 Lleida, Spain \\ ${ }^{\mathrm{b}}$ Mountain Research Centre (CIMO), Escola Superior Agrária/Instituto Politécnico de Bragança, Campus de Santa Apolónia, 5300-253 Bragança, Portugal
}

\section{A R T I C L E I N F O}

\section{Keywords:}

Allometric growth

Bisaro pig

Dissection

Fat

Lean

Meat

\begin{abstract}
A B S T R A C T
Carcass cuts and tissue composition were assessed in Bisaro pigs $(n=64)$ from two sexes (31 gilts and 33 entire males) reared until three target slaughter body-weights (BW) means: $17 \mathrm{~kg}, 32 \mathrm{~kg}$, and $79 \mathrm{~kg}$. Dressing percentage and backfat thickness increased whereas carcass shrinkage decreased with increasing BW. Slaughter weight affected most of the carcass cut proportions, except shoulder and thoracic regions. Bone proportion decreased linearly with increasing slaughter BW, while intermuscular and subcutaneous adipose tissue depots increased concomitantly. Slaughter weight increased the subcutaneous adipose tissue proportion but this impaired intramuscular and intermuscular adipose tissues in the loin primal. The sex of the pigs minimally affected the carcass composition, as only the belly weight and the subcutaneous adipose tissue proportions were greater in gilts than in entire males. Light pigs regardless of sex are recommended to balance the trade-offs between carcass cuts and their non-edible compositional outcomes.
\end{abstract}

\section{Introduction}

The assessment of differential growth (or allometric growth) allows understanding the transformation of body composition from birth to maturity. Lean and adipose tissues are the two main edible components of an animal's carcass, but lean requires lesser amounts of energy for deposition than adipose tissue (Warriss, 2004). In addition, the tissue growth rate is affected by sex, at least after $60 \mathrm{~kg}$ of body-weight (NRC, 2012), and thereby the slaughter weight may affect carcass composition (both commercial cuts and edible tissues).

It has been suggested that the partition of fat between depots in pigs may be changed as a result of selection for leaner carcasses (Jones, Richmond, Price, \& Berg, 1980), which has been a steady criterion in most swine breeds throughout the last years. However, the positive effect of intramuscular fat on the organoleptic characteristics of the meat cannot be displaced (Wood, Jones, Francombe, \& Wheleham, 1986). The intramuscular fat depot develops largely in parallel with other adipose tissue depots, but is also dependent on muscle growth (Hocquette et al., 2010). The intramuscular fat content is a fat depot that is not normally taken into account when dissecting carcass cuts, as it cannot be determined without chemical analysis of muscle, and thus fat-free lean mass is not correctly measured. In this regard, Eggert, Grant, and Schinckel (2007) observed that fat-free lean of pig carcasses was dependent on the lean content of genetic types. Overall, the synergic or antagonistic role of intramuscular fat along with the rest of carcass adipose tissue development is poorly understood.

In Portugal, the pork carcass cut and tissue composition have not been described in detail in some breeds, as Bisaro (a local Celtic breed raised in northern area of Portugal), because they have been overlooked in comparison with other fairly known breeds, as Iberian or 'Porco Preto' (Teixeira \& Rodrigues, 2013) (raised in the southern areas of the country). At present, there is an increasing interest in Bisaro breed to produce premium pork meat products, with two types of carcasses being accepted within its protected designation origin (PDO), the suckling piglets with up to $12 \mathrm{~kg}$ of carcass weight and the pigs with $>60 \mathrm{~kg}$ of carcass weight (graded as $<50 \%$ lean content) (Official Journal of the European Union, 2007). Nowadays, approximately 6400 breeding sows are currently registered in the National Bísaro Pig Producer Association (Paixão, Esteves, \& Payan-Carreira, 2018). The aim of this study was to determine the carcass cuts and tissue composition, as well as the development of tissues in the carcass of Bisaro pigs from two sexes (gilts and entire males).

\section{Material and methods}

\subsection{Animal husbandry and slaughter procedure}

A total of 64 Bisaro pigs, 31 gilts and 33 entire males, from the same

\footnotetext{
* Corresponding author.

E-mail address: teixeira@ipb.pt (A. Teixeira).
} 
batch were raised in a commercial farm (Bisaro Salsicharia Tradicional $^{\circledR}$ ) from north-Eastern Portugal (Gimonde, Bragança, Portugal) until three sequential target slaughter body-weights (BW) means: $17 \mathrm{~kg}(n=23,12$ gilts and 11 entire males), $32 \mathrm{~kg}(n=18,11$ gilts and 7 entire males), and $79 \mathrm{~kg}(\mathrm{n}=23,8$ gilts and 15 entire males). The piglets suckled their dams and received creep feeding ( $17 \%$ of crude protein (CP), $1.34 \%$ of lysine (Lys) and $5.0 \%$ of crude fat (CF)) during the first 5 weeks of age. Thereafter, they were supplied starter feed $(16.7 \%$ of CP, $1.2 \%$ of Lys and $6.5 \%$ of $\mathrm{CF}$ ) up to $25 \mathrm{~kg}$ of BW, growing feed (16.9\% of CP, $1.0 \%$ of Lys and $6.2 \%$ of CF) up to $60 \mathrm{~kg}$ of BW and finishing feed ( $13.5 \%$ of CP, $0.6 \%$ of Lys and $10.3 \%$ of CF) up to slaughter. The piglets were kept in outdoor paddocks during the growing and finishing phases (25-79 kg of BW). During this period, feed was supplied at $80 \%$ expected ad libitum intake to mimic a mildly harsh environment characteristic of the summer and winter periods.

At the target BW interval, the pigs were weighed individually at the farm prior to transportation to the abattoir (15-20 km distance). There, the pigs were electrically stunned, exsanguinated, scalded, dehaired, eviscerated, and split down the midline according to standard commercial procedures. The animal management was in compliance with European welfare guidelines. The carcasses were individually weighed immediately after slaughter (hot carcass) and $24 \mathrm{~h}$ later (cold carcass) to calculate the carcass shrinkage. The dressing percentage was calculated dividing the hot carcass weight (including head, jowl and feet) by the slaughter BW. Backfat thickness at 11th rib (including the skin and assuming the 15th rib was the last rib) and fat depth at Gluteus medius muscle were measured off the carcass midline (skin included) with a ruler in millimetres.

\subsection{Carcass joints and dissection}

After cooling at $4^{\circ} \mathrm{C}$ for $24 \mathrm{~h}$, the carcasses were carefully halved and weighed. The left side was cut into twelve commercial joints (head, jowl, nape of the neck, shank of the forelimb, shoulder, shoulder chops, thoracic region, loin primal (including chops), belly, leg, shank of the leg and the tail) based on Portugal standards (Swatland, 2004) (Fig. 1). Each joint was weighed and dissected with scalpel into lean, bone,
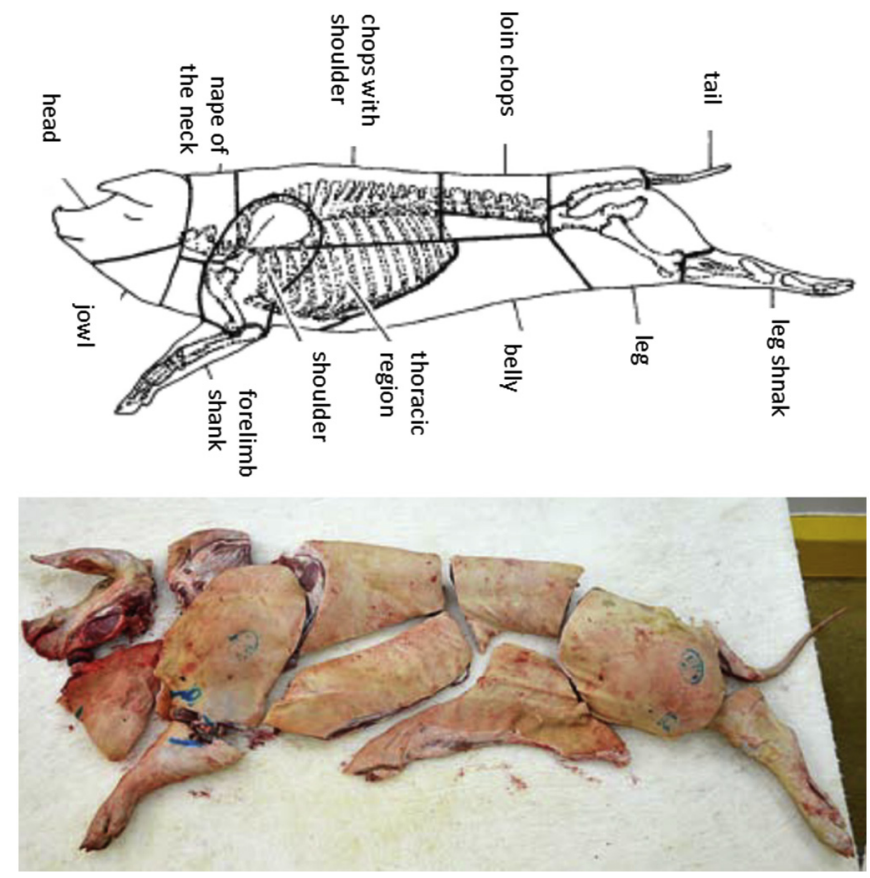

Fig. 1. Standardized carcass joints in Portugal (based on Swatland, 2004) (up) and their corresponding cuts in a Bisaro carcass (Fernandes \& Teixeira, 2015) (down). subcutaneous tissue, intermuscular tissue and remainder (major blood vessels, ligaments, tendons and thick connective tissue sheets associated with some lean), in a dissection room with a controlled environment. To split the contribution of fat-free lean (muscle) and intramuscular fat to the total weight of this joint, subcutaneous adipose tissue, intermuscular adipose tissue and intramuscular fat content were analysed in the boneless loin primal cuts by Sohxlet method (AOAC, 2000). Total adipose tissue in the loin primal was regarded as the sum of subcutaneous adipose tissue, intermuscular adipose tissue and intramuscular fat.

\subsection{Statistical analyses}

The statistical analyses were conducted using JMP (13.0.01 version; SAS Institute Inc., Cary, NC). Cuts and tissue composition of the carcass and the loin primal were analysed with a standard least square model that accounted for BW group, sex and their single interaction as fixed effects. Results are reported as least square means and their associated standard errors (SE). Multiple comparisons among treatments were performed by the Tukey method. The level of significance was set at 0.05 . The interactions are commented in the text only when they were significant $(P \leq .05)$.

Using half carcass weight and total carcass fat weight as independent variables (x), the relative growth coefficients (b) for each carcass component (y) were calculated from the allometric equation of Huxley (1932) $\left(y=a x^{b}\right)$. The data were first log transformed (base 10) and weights of each component (y) were then regressed on the independent variables (x), by applying the following model:

$\log Y_{i j k}=\log a+S W_{i}+S_{j}+b^{*} \log X_{i j k}+E_{i j k}$

where: $\log \mathrm{Y}$ is the weight of the depot of $k$ th animal; $\log$ a is the intercept; SW is the fixed effect of the ith slaughter weight $(17 \mathrm{~kg}, 32 \mathrm{~kg}$ or $79 \mathrm{~kg}$ ); $\mathrm{S}$ is the fixed effect of $j$ th sex (gilts or entire males); $\mathrm{X}$ is half carcass weight or carcass fat; and $\mathrm{b}$ is the regression coefficient on carcass weight or carcass fat (allometric coefficient), and $\mathrm{E}$ is the random error. The allometric growth coefficients for each dependent variable were tested for $b=1$ by means of their $95 \%$ confidence intervals, following the methods used by Álvarez-Rodríguez et al. (2009).

\section{Results}

\subsection{Carcass performance}

Carcass characteristics (weight, shrinkage, dressing percentage, fatness) are shown in Table 1 . The slaughter weight groups affected most of the carcass characteristics $(P<.05)$ except intramuscular fat content of loin meat (boneless primal) $(P>.05)$. Cold carcass weight and dressing percentage increased linearly with increasing BW $(P<.001)$, whereas carcass shrinkage, backfat thickness at 11 th rib and fat depth over the Gluteus medius muscle did not differ between $17 \mathrm{~kg}$ and $32 \mathrm{~kg}$ BW groups $(P>.05)$, but increased thereafter $(\mathrm{P}<.05)$, regardless of pig sex. The sex of the pigs did not affect any carcass parameter $(\mathrm{P}>$.05). Fat depth at Gluteus medius muscle $(\mathrm{mm})$ and intramuscular fat content (\% of loin meat) in gilts and entire males at 17,32 and $79 \mathrm{~kg}$ of slaughter weight is provided in Fig. 2.

\subsection{Carcass cuts}

The slaughter weight affected most of the carcass cut proportions (Table 2; $P<.01)$, except shoulder and thoracic regions $(P>.05)$. The head weight proportion increased linearly with increasing BW $(P<.001)$. However, the jowl, shoulder chops, the loin primal and the belly weight proportions did not differ between $17 \mathrm{~kg}$ and $32 \mathrm{~kg}$ of BW groups $(P>.05)$, but increased thereafter $(P<.05)$. By contrast, the nape of the neck, the shank of the forelimb and the shank of the leg weight proportions decreased with increasing BW $(P<.001)$. Finally, 
Table 1

Carcass performance in Bisaro pigs as affected by slaughter weight and sex

\begin{tabular}{|c|c|c|c|c|c|c|c|}
\hline & \multicolumn{3}{|c|}{ Slaughter weight } & \multicolumn{2}{|l|}{ Sex } & \multicolumn{2}{|l|}{$P$-value } \\
\hline & $17 \mathrm{~kg}$ & $32 \mathrm{~kg}$ & $79 \mathrm{~kg}$ & Gilts & Entire males & Slaughter weight & Sex \\
\hline $\mathrm{n}$ & 23 & 18 & 23 & 31 & 33 & - & - \\
\hline Slaughter weight (kg) & $16.6 \pm 2.5 \mathrm{a}$ & $32.0 \pm 2.9 \mathrm{~b}$ & $78.7 \pm 2.6 c$ & $41.6 \pm 2.2$ & $43.3 \pm 2.2$ & $<0.001$ & 0.58 \\
\hline Cold carcass weight $(\mathrm{kg})$ & $11.5 \pm 2.2 \mathrm{a}$ & $23.3 \pm 2.5 b$ & $60.8 \pm 2.3 c$ & $31.3 \pm 1.9$ & $32.4 \pm 1.9$ & $<0.001$ & 0.68 \\
\hline Carcass shrinkage (\%) & $2.83 \pm 0.20 \mathrm{a}$ & $2.54 \pm 0.23 \mathrm{ab}$ & $2.02 \pm 0.21 b$ & $2.35 \pm 0.17$ & $2.57 \pm 0.17$ & 0.02 & 0.39 \\
\hline Dressing percentage (\%) & $69.5 \pm 0.7 a$ & $72.7 \pm 0.8 \mathrm{~b}$ & $76.8 \pm 0.7 c$ & $72.4 \pm 0.6$ & $73.6 \pm 0.6$ & $<0.001$ & 0.15 \\
\hline Backfat thickness at 11 th rib (mm) (including the skin) & $7 \pm 1 a$ & $7 \pm 2 a$ & $17 \pm 1 b$ & $10 \pm 1$ & $11 \pm 1$ & $<0.001$ & 0.70 \\
\hline Fat depth over Gluteus medius muscle (including the skin) (mm) & $3 \pm 2 a$ & $7 \pm 1 \mathrm{a}$ & $15 \pm 1 b$ & $9 \pm 1$ & $8 \pm 1$ & $<0.001$ & 0.60 \\
\hline Intramuscular fat content in boneless loin primal ( $\mathrm{g} / 100 \mathrm{~g}$ of meat) & $1.17 \pm 0.10$ & $1.34 \pm 0.12$ & $1.47 \pm 0.11$ & $1.20 \pm 0.09$ & $1.44 \pm 0.09$ & 0.15 & 0.07 \\
\hline
\end{tabular}

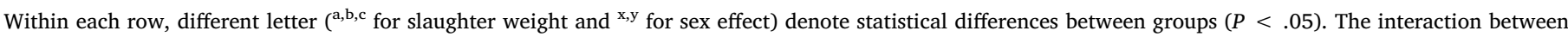
slaughter weight and sex was not significant $(P>.05)$ in any variable.

the leg and the tail weight proportions increased significantly between $17 \mathrm{~kg}$ and $32 \mathrm{~kg}$ of BW $(\mathrm{P}<.001)$, but remained unaffected thereafter $(P>.05)$.

The sex of the pigs minimally affected the carcass cuts composition, as only the belly weight proportions were greater in gilts than in entire males (Table 2; $\mathrm{P}<.001$ ).

The analyses of allometric coefficients of carcass cuts showed that the head, the shank of the forelimb and the shank of the leg grew slower than the whole carcass ( $\mathrm{b}<1, P<.001$; Table 2), while the rest of the carcass cuts grew at similar rate than the whole carcass $(b=1$, $P>.05)$. In addition, the high $R^{2}$ values $(R 2=0.89-0.99)$ showed that a large part of the variation in each carcass cut was accounted for by the statistical model. The standard error of allometric growth coefficients of carcass cuts was higher for jowl, the loin primal, shoulder and tail than for the rest of carcass cuts.

\subsection{Whole carcass tissue composition}

The slaughter weight affected the whole carcass tissue composition (Table 3; $P<.001$ ). The bone proportion decreased linearly with increasing BW at slaughter $(\mathrm{P}<.001)$, while intermuscular and subcutaneous adipose tissues increased concomitantly $(P<.001)$. The percentage of fat in intermuscular adipose tissue was $76.1 \pm 1.3 \%$ whereas the percentage of fat in subcutaneous adipose tissue was $89.4 \pm 0.8 \%$. The lean content was higher in lighter pigs $(17 \mathrm{~kg}$ and $32 \mathrm{~kg}$ of BW) than in the heavier pig group $(79 \mathrm{~kg}$ of BW) $(P<.05)$. Likewise, the skin proportion was greater in pigs showing $17 \mathrm{~kg}$ of BW at slaughter than subsequently $(\mathrm{P}<.05)$.

The sex of the pigs only affected the subcutaneous adipose tissue proportion, that was greater in gilts than in entire males (Table 3; $\mathrm{P}<.05)$.

The analyses of allometric coefficients of carcass tissues showed that

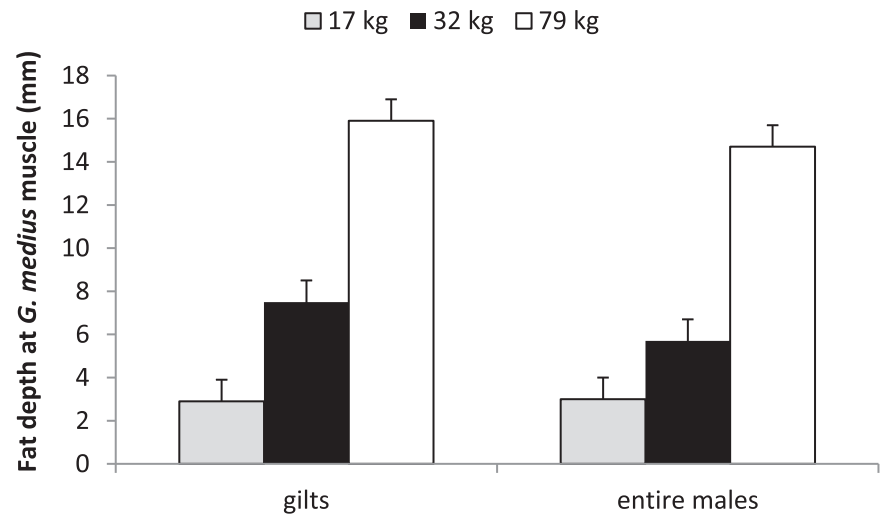

the bone and the skin grew slower that did the rest of the carcass (b $<1, P<.001$; Table 3 ), whereas the lean grew at similar rate than the whole carcass $(\mathrm{b}=1, P>.05)$, and intermuscular and subcutaneous adipose tissues grew faster than did the whole carcass (b $>1, \mathrm{P}<.001$ ). In addition, the high $\mathrm{R}^{2}$ values $(\mathrm{R} 2=0.96-0.99)$ showed that a large part of the variation in each carcass tissue was accounted for by the statistical model. The standard error of allometric growth coefficients of carcass tissues was higher for subcutaneous and intermuscular adipose tissues than for skin, bone and lean tissues.

\subsection{Loin primal tissue composition}

The bone proportion in the loin primal was greater in the lightest pigs ( $17 \mathrm{~kg}$ of BW) compared to the rest of pig groups (32 and $79 \mathrm{~kg}$ of BW) (Table 4; $P<.05$ ). In addition, the fat-free lean proportion in the loin primal was greater at $17 \mathrm{~kg}$ and $32 \mathrm{~kg}$ of BW than at $79 \mathrm{~kg} \mathrm{BW}$ $(\mathrm{P}<.05)$. The skin proportion in loin primal showed an irregular pattern, with lowest values in $32 \mathrm{~kg}$ BW pigs $(\mathrm{P}<.05)$. Concerning fat depots in the loin primal, intermuscular and subcutaneous adipose tissues increased linearly with increasing BW at slaughter $(\mathrm{P}<.05)$, but intramuscular fat content did not differ across BW groups $(P>.05)$.

The sex of the pigs only affected the intramuscular fat proportion in the loin primal (Table 4; $\mathrm{P}<.05$ ), that was lower in gilts than in entire males.

The analyses of allometric coefficients of the loin primal tissues showed that the bone and the fat-free lean grew slower than did the rest of the loin primal ( $b<1, P<.001$; Table 4 ), whereas the skin, intramuscular fat and intermuscular adipose tissue grew at similar rate ( $\mathrm{b}=1, \mathrm{P}>.05$ ), and subcutaneous adipose tissue grew faster than did the loin primal $(\mathrm{b}>1, \mathrm{P}<.001)$. In addition, the $\mathrm{R}^{2}$ values were lower for intermuscular and intramuscular fat depots $\left(R^{2}=0.83-0.85\right)$

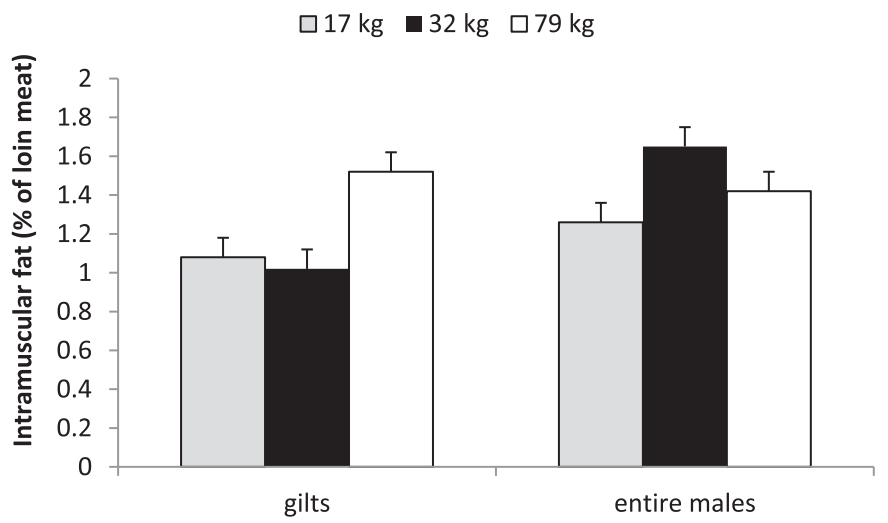

Fig. 2. Fat depth at Gluteus medius muscle (mm) and intramuscular fat content (\% of loin meat) in gilts and entire males at 17, 32 and $79 \mathrm{~kg}$ of slaughter weight (No interaction between BW group and sex was detected in any variable, $P>.05$ ). 
Table 2

Carcass cut proportions in Bisaro pigs as affected by slaughter weight and sex, and their associated allometric coefficients (b) in relation to carcass weight.

\begin{tabular}{|c|c|c|c|c|c|c|c|c|c|}
\hline & \multicolumn{3}{|c|}{ Slaughter weight } & \multicolumn{2}{|l|}{ Sex } & \multicolumn{2}{|l|}{ Allometry $^{1}$} & \multicolumn{2}{|l|}{ P-value } \\
\hline & $17 \mathrm{~kg}$ & $32 \mathrm{~kg}$ & $79 \mathrm{~kg}$ & Gilts & Entire males & $\mathrm{b} \pm \mathrm{SE}$ & $\mathrm{R}^{2}$ & Slaughter weight & Sex \\
\hline Half cold carcass weight $(\mathrm{kg})$ & $5.58 \pm 1.06 a$ & $11.27 \pm 1.23 \mathrm{~b}$ & $30.40 \pm 11.14 \mathrm{c}$ & $15.55 \pm 0.93$ & $15.95 \pm 0.93$ & - & - & $<0.001$ & 0.76 \\
\hline Head (\%) & $10.5 \pm 0.2 c$ & $8.7 \pm 0.3 b$ & $7.2 \pm 0.3 a$ & $8.6 \pm 0.2$ & $9.0 \pm 0.2$ & $0.78 \pm 0.07 *$ & 0.96 & $<0.001$ & 0.16 \\
\hline Jowl (\%) & $1.55 \pm 0.12 \mathrm{a}$ & $1.66 \pm 0.14 \mathrm{a}$ & $3.02 \pm 0.12 b$ & $2.19 \pm 0.10$ & $1.96 \pm 0.10$ & $1.04 \pm 0.17$ & 0.93 & $<0.001$ & 0.11 \\
\hline Nape of the neck (\%) & $7.90 \pm 0.26 b$ & $8.03 \pm 0.30 \mathrm{~b}$ & $5.52 \pm 0.27 a$ & $7.26 \pm 0.22$ & $7.04 \pm 0.22$ & $0.91 \pm 0.10$ & 0.93 & $<0.001$ & 0.49 \\
\hline Shank of the forelimb (\%) & $4.78 \pm 0.11 b$ & $4.14 \pm 0.13 a$ & $3.94 \pm 0.12 \mathrm{a}$ & $4.18 \pm 0.10$ & $4.39 \pm 0.10$ & $0.70 \pm 0.06^{*}$ & 0.98 & $<0.001$ & 0.12 \\
\hline Shoulder (\%) & $12.9 \pm 0.4$ & $11.7 \pm 0.4$ & $12.8 \pm 0.4$ & $12.1 \pm 0.3$ & $12.9 \pm 0.3$ & $1.11 \pm 0.17$ & 0.88 & 0.07 & 0.08 \\
\hline Shoulder chops (\%) & $11.9 \pm 0.3 a$ & $13.1 \pm 0.4 \mathrm{ab}$ & $13.8 \pm 0.4 b$ & $13.1 \pm 0.3$ & $12.8 \pm 0.3$ & $1.14 \pm 0.07$ & 0.98 & $<0.002$ & 0.38 \\
\hline Thoracic region (\%) & $8.64 \pm 0.23$ & $8.81 \pm 0.26$ & $9.37 \pm 0.24$ & $9.09 \pm 0.20$ & $8.79 \pm 0.20$ & $1.06 \pm 0.07$ & 0.98 & 0.08 & 0.29 \\
\hline Loin primal (\%) & $6.65 \pm 0.25 a$ & $6.39 \pm 0.29 a$ & $7.95 \pm 0.26 b$ & $6.88 \pm 0.22$ & $7.11 \pm 0.22$ & $1.33 \pm 0.18$ & 0.89 & $<0.001$ & 0.47 \\
\hline Belly (\%) & $5.69 \pm 0.21 \mathrm{a}$ & $5.98 \pm 0.25 a b$ & $6.78 \pm 0.22 b$ & $6.69 \pm 0.19 \times$ & $5.60 \pm 0.19 y$ & $1.14 \pm 0.11$ & 0.96 & 0.003 & $<0.001$ \\
\hline Leg (\%) & $22.5 \pm 0.4 a$ & $25.0 \pm 0.4 b$ & $23.8 \pm 0.4 b$ & $23.5 \pm 0.3$ & $24.1 \pm 0.3$ & $1.01 \pm 0.05$ & 0.99 & $<0.001$ & 0.14 \\
\hline Shank of the leg (\%) & $6.33 \pm 0.13 c$ & $5.73 \pm 0.15 b$ & $5.02 \pm 0.14 a$ & $5.74 \pm 0.11$ & $5.64 \pm 0.11$ & $0.67 \pm 0.05^{*}$ & 0.98 & $<0.001$ & 0.53 \\
\hline Tail (\%) & $0.53 \pm 0.03 a$ & $0.70 \pm 0.04 b$ & $0.80 \pm 0.04 b$ & $0.68 \pm 0.03$ & $0.67 \pm 0.03$ & $1.06 \pm 0.17$ & 0.92 & $<0.001$ & 0.93 \\
\hline
\end{tabular}

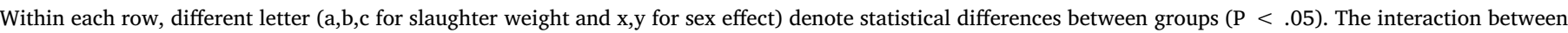
slaughter weight and sex was not significant $(P>.05)$ in any variable.

$1 *=\mathrm{b} \neq 1$ with $P<.001$.

than for the rest of the loin primal tissues $\left(R^{2} \geq 0.94\right)$. The standard error of allometric growth coefficients of the loin primal tissues was higher for intermuscular and subcutaneous adipose tissues and intramuscular fat than for skin, bone and fat-free lean tissues.

\subsection{Fat distribution in the loin primal}

The fat tissue distribution in the loin primal is shown in Table 5. The slaughter weight decreased the intramuscular fat and intermuscular adipose tissue proportions in relation to total adipose tissue in the loin primal, whereas the subcutaneous adipose tissue proportion increased concomitantly $(P<.05)$.

The sex of the pigs did not affect the intramuscular or intermuscular adipose tissue proportions in the loin primal (Table $5 ; P>$.05) but only the subcutaneous adipose tissue depot, which was greater in gilts than in entire males $(\mathrm{P}<.05)$.

The allometric growth of adipose tissue in the loin primal was similar for intramuscular and intermuscular adipose tissue, that grew at slower rates than did the whole fat content (b $<1 ; P<.001$; Table 5). By contrast, subcutaneous adipose tissue grew at faster rates than did the whole fat content in the loin primal $(\mathrm{b}>1$; $\mathrm{P}<.001)$.

\section{Discussion}

\subsection{Carcass performance and cuts}

This paper fills a knowledge gap in relation to carcass and tissue composition of local swine breeds, especifically Bisaro pigs from Portugal. The lightest pigs analysed would meet the requirements of
Bisaro suckling piglets protected designation origin (PDO) $(<12 \mathrm{~kg}$ cold carcass weight), while the heaviest pigs would meet the requirements of Bisaro pork PDO ( $>60 \mathrm{~kg}$ of carcass weight and graded as $<50 \%$ lean content). Subcutaneous adipose tissue depth increased throughout the growing period (17-79 kg of BW), but in 79-kg BW pigs the most striking increase was observed in Gluteus medius muscle compared to backfat thickness at 11th rib. A similar trend was observed by Muth, Huyen, Markemann, and Valle Zárate (2017) in Ban pigs (a local breed from Vietnam) also slaughtered at light BW to avoid excessive fat accumulation. Concerning carcass cuts composition, the main finding of this study was that their proportions were especially affected by slaughter weight but not by pig sex. This outcome may be related to slaughter weight rather than age selection of target pigs, which had similar age between sexes in 17-kg group ( 9 weeks of age) and 32-kg group (14 weeks of age), but entire males were younger than gilts in 79-kg group (10 vs. 12 months of age, respectively).

In other works using heavy crossbred pigs for Teruel dry-cured ham production, the shoulder yield was not affected by increasing the slaughter weight from 120 to $140 \mathrm{~kg}$, but the whole primal cuts (loin + ham + shoulder) yield decreased accordingly (Latorre, GarcíaBelenguer, \& Ariño, 2008). However, in the current genetic type and BW range (light Bisaro pigs), the shoulder chops, the loin primal, the belly and the ham increased their yields with increasing mean slaughter weight from 17 to $79 \mathrm{~kg}$. However, neither shoulder nor the thoracic region yields were affected by slaughter weight.

Within the studied slaughter weight range, the growth rate of most of the carcass joints accompanied the rest of carcass growth $(b=1$, $P>$.05). This would indicate that carcass cuts yields increased steadily and there were no yield penalties for main carcass cuts (shoulder,

Table 3

Carcass tissue proportions (\%, or $\mathrm{g} / 100 \mathrm{~g}$ of carcass weight) in Bisaro pigs as affected by slaughter weight and sex, and their associated allometric coefficients (b) in relation to carcass weight.

\begin{tabular}{|c|c|c|c|c|c|c|c|c|c|}
\hline & \multicolumn{3}{|l|}{ Slaughter weight } & \multicolumn{2}{|l|}{ Sex } & \multicolumn{2}{|l|}{ Allometry } & \multicolumn{2}{|l|}{ P-value } \\
\hline & $17 \mathrm{~kg}$ & $32 \mathrm{~kg}$ & $79 \mathrm{~kg}$ & Gilts & Entire males & $\mathrm{b} \pm \mathrm{SE}^{1}$ & $\mathrm{R}^{2}$ & Slaughter weight & Sex \\
\hline Bone plus remainder $(\%)^{2}$ & $27.49 \pm 0.54 c$ & $22.86 \pm 0.63 b$ & $18.80 \pm 0.59 \mathrm{a}$ & $22.58 \pm 0.49$ & $23.51 \pm 0.47$ & $0.66 \pm 0.05^{*}$ & 0.98 & $<0.001$ & 0.18 \\
\hline Skin (\%) & $11.64 \pm 0.26 \mathrm{a}$ & $8.93 \pm 0.30 b$ & $9.57 \pm 0.28 b$ & $9.87 \pm 0.23$ & $10.22 \pm 0.22$ & $0.83 \pm 0.07^{*}$ & 0.97 & $<0.001$ & 0.28 \\
\hline Lean $(\%)$ & $52.88 \pm 0.70 \mathrm{a}$ & $54.50 \pm 0.81 \mathrm{a}$ & $46.60 \pm 0.77 b$ & $50.89 \pm 0.63$ & $51.76 \pm 0.61$ & $0.94 \pm 0.04$ & 0.99 & $<0.001$ & 0.33 \\
\hline Intermuscular adipose tissue (\%) & $3.83 \pm 0.21 \mathrm{a}$ & $5.24 \pm 0.25 b$ & $7.17 \pm 0.23 c$ & $5.31 \pm 0.19$ & $5.51 \pm 0.19$ & $1.36 \pm 0.12 *$ & 0.96 & $<0.001$ & 0.45 \\
\hline Subcutaneous adipose tissue (\%) & $4.09 \pm 0.79 a$ & $8.46 \pm 0.91 b$ & $17.65 \pm 0.87 \mathrm{c}$ & $11.30 \pm 0.71 \times$ & $8.83 \pm 0.69 y$ & $1.89 \pm 0.17^{*}$ & 0.96 & $<0.001$ & 0.02 \\
\hline
\end{tabular}

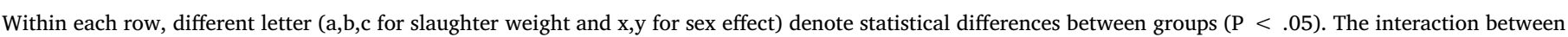
slaughter weight and sex was not significant $(\mathrm{P}>.05)$ in any variable.

$1 *=\mathrm{b} \neq 1$ with $\mathrm{P}<.001$.

${ }^{2}$ Remainder was considered as major blood vessels, ligaments, tendons and thick connective tissue sheets. 
Table 4

Loin primal tissue proportions (\%, or $\mathrm{g} / 100 \mathrm{~g}$ of loin primal) in Bisaro pigs as affected by slaughter weight and sex, and their associated allometric coeficients (b) in relation to loin primal weight.

\begin{tabular}{|c|c|c|c|c|c|c|c|c|c|}
\hline & \multicolumn{3}{|l|}{ Slaughter weight } & \multicolumn{2}{|l|}{ Sex } & \multicolumn{2}{|l|}{ Allometry $^{1}$} & \multicolumn{2}{|l|}{$P$-value } \\
\hline & $17 \mathrm{~kg}$ & $32 \mathrm{~kg}$ & $79 \mathrm{~kg}$ & Gilts & Entire males & $\mathrm{b} \pm \mathrm{SE}$ & $\mathrm{R}^{2}$ & Slaughter weight & Sex \\
\hline Half loin primal weight (kg) & $0.36 \pm 0.10 \mathrm{a}$ & $0.71 \pm 0.12 b$ & $2.25 \pm 0.11 c$ & $1.05 \pm 0.09$ & $1.16 \pm 0.09$ & - & - & $<0.001$ & 0.39 \\
\hline Bone plus remainder $(\%)^{3}$ & $24.46 \pm 0.84 b$ & $17.12 \pm 0.98 \mathrm{a}$ & $16.04 \pm 0.93 a$ & $18.88 \pm 0.76$ & $19.53 \pm 0.74$ & $0.73 \pm 0.08^{*}$ & 0.94 & $<0.001$ & 0.54 \\
\hline Fat-free lean (\%) & $60.64 \pm 1.19 b$ & $62.43 \pm 1.34 b$ & $47.43 \pm 1.34 \mathrm{a}$ & $56.66 \pm 1.06$ & $57.00 \pm 1.06$ & $0.86 \pm 0.04^{*}$ & 0.98 & $<0.001$ & 0.81 \\
\hline Skin (\%) & $8.44 \pm 0.27 b$ & $6.00 \pm 0.32 \mathrm{a}$ & $7.47 \pm 0.30 \mathrm{~b}$ & $6.99 \pm 0.25$ & $7.62 \pm 0.24$ & $0.91 \pm 0.08$ & 0.96 & $<0.001$ & 0.07 \\
\hline Intermuscular adipose tissue (\%) & $2.58 \pm 0.35 \mathrm{a}$ & $4.23 \pm 0.41 b$ & $5.90 \pm 0.39 c$ & $4.17 \pm 0.32$ & $4.31 \pm 0.31$ & $1.03 \pm 0.26$ & 0.83 & $<0.001$ & 0.75 \\
\hline Intramuscular fat ${ }^{2}(\%)$ & $0.72 \pm 0.06$ & $0.84 \pm 0.07$ & $0.71 \pm 0.07$ & $0.68 \pm 0.05 \times$ & $0.83 \pm 0.05 y$ & $1.21 \pm 0.18$ & 0.85 & 0.28 & 0.04 \\
\hline Subcutaneous adipose tissue (\%) & $3.15 \pm 1.23 \mathrm{a}$ & $9.39 \pm 1.43 b$ & $22.43 \pm 1.37 c$ & $12.61 \pm 1.11$ & $10.69 \pm 1.09$ & $2.11 \pm 0.20^{*}$ & 0.94 & $<0.001$ & 0.22 \\
\hline
\end{tabular}

Within each row, different letter $\left(^{\mathrm{a}, \mathrm{b}, \mathrm{c}}\right.$ for slaughter weight and ${ }^{\mathrm{x}, \mathrm{y}}$ for sex effect) denote statistical differences between groups $(P<.05)$. The interaction between slaughter weight and sex was not significant $(P>.05)$ in any variable.

$1 *=\mathrm{b} \neq 1$ with $P<.001$.

${ }^{2}$ Intramuscular fat relative to loin primal weight (including bone and subcutaneous adipose tissue).

${ }^{3}$ Remainder was considered as major blood vessels, ligaments, tendons and thick connective tissue sheets.

shoulder chops, thoracic region, loin primal, belly and leg) with increasing the slaughter weight mean up to $79 \mathrm{~kg}$. However, this was not observed in crossbred pigs intended for dry-cured industry, as the ham and loin allometric growth coefficients were lower in heavy than in light pigs (Latorre et al., 2019), and thus, at heavy weights these cuts increased slower than the overall carcass, which was attributed to greater accretion of fat rather than other tissues.

It must be pointed out that the simple allometric equation assumes that the growth percentage of each carcass cut and tissue was decreasing, increasing or remaining constant for the whole carcass weight range (10-65 kg) studied. Hence, this static allometric growth model is useful to understand carcass tissue development but it might represent a constraint for analysing some other ontogenic developmental characteristics.

The sex of the pigs was a minor factor affecting carcass cut yields within the present slaughter weight range (17-79 kg BW), as only an increased belly yield was observed in gilts compared to entire males, which may be attributed to their lower subcutaneous fatness in the latter. In this study, this observation is conditioned by the lack of castration of male pigs, as in heavy Celta pigs (a close breed to Bisaro) (130-140 kg of BW at slaughter), gilts showed lower belly yield than barrows (Franco \& Lorenzo, 2013). In fact, the sex becomes an important determinant to condition the fat-free lean content of the belly, which is reduced in heavy commercial barrows above $94 \mathrm{~kg}$ of carcass weight (Duziński, Knecht, Lisiak, \& Janiszewski, 2015).

\subsection{Carcass tissue composition}

The calculated allometric growth coefficients for Bisaro pigs are in agreement with Siewerdt, Farias, Osório, and Jacondino (1994), who found that an increase of carcass weight corresponded to a similar increase of lean, but also corresponded to a larger increase of pork adipose tissues. Therefore, they recommended the slaughtering of lighter pigs, with body-weight close to $90 \mathrm{~kg}$, to avoid undesirable amount of fat in the carcass, which may be extrapolated to desired market specifications for Bisaro pork.

However, not the whole carcass fat depots grow at similar rates. For instance, the dissection of hams from heavy pigs $(124-183 \mathrm{~kg}$ at slaughter) revealed that the intramuscular fat depot exhibited the lowest allometric coefficient (statistically not different from the unity, $\mathrm{b}=1$ ) compared to the rest of ham fat depots (intermuscular and subcutaneous fat, with $b>1$ ) (Franci, Pugliese, Bozzi, Acciaioli, \& Parisi, 2001). This led to conclude that the increase of body-weight did not notably increase the fat content in ham muscles during this developmental range. In this study, the fat depots in the loin primal followed a similar developmental growth pattern to the afore-mentioned work (in early maturing order: intramuscular $>$ intermuscular $>$ subcutaneous). Consistently, the high $\mathrm{R}^{2}$ values and the low standard error of most of the calculated allometric coefficients explained a large part of the variation of dissected tissues data.

The selection for leanness has been less successful for reducing intermuscular than for reducing subcutaneous fat in pigs, as previously discussed by Gu, Schinckel, and Martin (1992). Indeed, Kouba, Bonneau, and Noblet (1999) observed that the leaner the pigs genetically, the higher the proportion of intermuscular adipose tissue in total adipose tissue. These authors concluded that the development of intermuscular fat in pigs may be determined at an early stage, before $20 \mathrm{~kg}$ of body-weight, which is consistent with the current results.

Although intermuscular fat cannot be easily removed from fresh pork (Kouba \& Sellier, 2011), marbling is the most important fat depot influencing consumer acceptability of pork; both from a taste view (Font-i-Furnols, Tous, Esteve-Garcia, \& Gispert, 2012) and from a visual appeal view (Argemí-Armengol, Villalba, Ripoll, Teixeira, \& ÁlvarezRodríguez, 2019). However, not the whole pig breeds may display

Table 5

Fat tissue proportions (\%, or g/100 of total fat) in Bisaro pigs as affected by slaughter weight and sex, and their associated allometric coeficients (b) in relation to total fat weight in the loin primal.

\begin{tabular}{|c|c|c|c|c|c|c|c|c|c|}
\hline & \multicolumn{3}{|l|}{ Slaughter weight } & \multicolumn{2}{|l|}{ Sex } & \multicolumn{2}{|l|}{ Allometry } & \multicolumn{2}{|l|}{ P-value } \\
\hline Total fat weight in the loin primal $(\mathrm{g})$ & $24.7 \pm 47.8 \mathrm{a}$ & $110.7 \pm 54.2 \mathrm{~b}$ & $690.1 \pm 54.2 \mathrm{c}$ & $280.4 \pm 42.6$ & $269.9 \pm 42.6$ & - & - & $<0.001$ & 0.86 \\
\hline Intermuscular adipose tissue (\%) & $38.31 \pm 3.10 \mathrm{~b}$ & $32.10 \pm 3.52 \mathrm{ab}$ & $23.10 \pm 3.52 \mathrm{a}$ & $28.03 \pm 2.76$ & $34.32 \pm 2.76$ & $0.77 \pm 0.10^{*}$ & 0.90 & 0.008 & 0.11 \\
\hline Subcutaneous adipose tissue (\%) & $48.53 \pm 3.20 \mathrm{a}$ & $61.51 \pm 3.62 \mathrm{~b}$ & $74.24 \pm 3.62 c$ & $65.59 \pm 2.85 \times$ & $57.27 \pm 2.85 y$ & $1.14 \pm 0.07 *$ & 0.97 & $<0.001$ & 0.04 \\
\hline
\end{tabular}

Within each row, different letter $\left(^{\mathrm{a}, \mathrm{b}, \mathrm{c}}\right.$ for slaughter weight and ${ }^{\mathrm{x}, \mathrm{y}}$ for sex effect) denote statistical differences between groups $(\mathrm{P}<.05)$. The interaction between slaughter weight and sex was not significant $(P>.05)$ in any variable.

$1 *=\mathrm{b} \neq 1$ with $\mathrm{P}<.001$.

${ }^{2}$ Remainder was considered as major blood vessels, ligaments, tendons and thick connective tissue sheets. 
increased intramuscular fat by increasing their slaughter weight. The current results would suggest that increasing the slaughter weight up to $79 \mathrm{~kg}$ did not lead to increased marbling (intramuscular fat), but only boosted the intermuscular and subcutaneous fat depot proportions in the carcass, to the detriment of fat-free lean and bone tissues proportions. Hence, larger maturing of Bisaro pigs does not seem to increase their intramuscular fat deposition. In some purebred Duroc lines following a strict breeding programme to improve marbling without hampering their subcutaneous fat content (Ros-Freixedes, Reixach, Bosch, Tor, \& Estany, 2013), Álvarez-Rodríguez et al. (2018) found that an increase in slaughter weight up to $139 \mathrm{~kg}$ increased their intramuscular fat content in loins. On the contrary, this was not observed in crossbreds, which did not increased their intramuscular fat content in loins by increasing their slaughter weight from 69 to $120 \mathrm{~kg}$ (Duroc sires mated to Large-White $\times$ Landrace dams) (D'Souza et al., 2004), or from 116 to $133 \mathrm{~kg}$ (Pietrain $\times$ Large White sires mated to Landrace $\times$ Large White dams) (Latorre, Lázaro, Valencia, Medel, \& Mateos, 2004). In fact, Hocquette et al. (2010) described that animals having a high muscularity with a high glycolytic activity display a reduced development of intramuscular fat. However, in the present study, the low marbling of Bisaro pigs may not be related to increased muscle conformation, as this was an unselected breed whose breeding programme is focused yet on improving the stock number of sows with unambiguous phenotypical traits (Paixão et al., 2018). To increase intramuscular fat content in the loin primal from Bisaro pork at light slaughter weights, additional strategies based on reduced dietary lysine and/or increased dietary energy content might be required, as shown elsewhere in other genetic types (Suárez-Belloch, Latorre, \& Guada, 2016; Suarez-Belloch, Sanz, Joy, \& Latorre, 2013).

The subcutaneous adipose tissue depot accounted for a greater proportion of carcass weight and total adipose tissue in gilts than in entire males. However, no differences were detected between sexes in subcutaneous adipose tissue proportion with regard to the loin primal weight. In general, the studies analysing the sex effect in pigs compare the carcass tissues of gilts and barrows (castrated males to avoid boar taint at heavy weights). In such case, barrows have greater fat depots than gilts at similar slaughter weight (Latorre, Ripoll, García-Belenguer, \& Ariño, 2009). However, at $110 \mathrm{~kg}$ of slaughter weight, Gispert et al. (2010) described that gilts have lower lean and greater subcutaneous fat proportion in the carcass than entire males, although no differences were detected in the intramuscular fat content of meat, which is in line with the observed results in the 79-kg BW pigs.

\section{Conclusions}

In conclusion, an increase of slaughter weight in Bisaro pigs involved greater proportion of jowl, shoulder chops, loin primal, leg, belly and tail in the carcass. The bone proportion decreased linearly with increasing BW at slaughter, while intermuscular and subcutaneous adipose tissue in the carcass increased concomitantly. Slaughter weight increased subcutaneous adipose tissue proportion in relation to total adipose tissue in the loin primal, to the detriment of intramuscular fat and intermuscular adipose tissue proportions. The sex of the pigs did not affect carcass parameters, and minimally affected carcass cut composition, as only the belly weight and the subcutaneous adipose tissue proportions were greater in gilts than in entire males. The bone and thefat-free lean grew slower that did the rest of the loin primal (b $<1$ ); the skin, intramuscular fat and intermuscular adipose tissue grew at similar rate $(b=1)$, and subcutaneous adipose tissue grew faster $(b>1)$. Unless sausage products with high fat content are required, light Bisaro pigs regardless of sex are recommended to balance the trade-offs between carcass cuts and their non-edible compositional outcomes.

\section{Acknowledgements}

Work included in the Portuguese PRODER research Project BISOPORC - Pork extensive production of Bísara breed, in two alternative systems: fattening on concentrate vs chesnut, Project PRODER SI I\&DT Medida 4.1 "Cooperação para a Inovação". The authors are grateful to Laboratory of Carcass and Meat Quality of Agriculture School of Polytechnic Institute of Bragança 'Cantinho do Alfredo'. The authors are members of the MARCARNE network, funded by CYTED (ref. 116RT0503).

\section{Declarations of interest}

None.

\section{References}

Álvarez-Rodríguez, J., Ros-Freixedes, R., Gol, S., Henríquez-Rodríguez, E., Pena, R. N., Bosch, L., ... Tor, M. (2018). Carcass lean-yield effects on the fatty acid and amino acid composition of Duroc pork and its technological quality after vacuum-aging. Animal Production Science, 58, 2335-2343.

Álvarez-Rodríguez, J., Sanz, A., Joy, M., Carrasco, S., Ripoll, G., \& Teixeira, A. (2009). Development of organs and tissues in lambs raised on Spanish mountain grassland. Canadian Journal of Animal Science, 89, 37-45.

AOAC (2000). Official methods of analysis (17th ed.). Arlington, VA, USA: Association of Official Agricultural Chemists International.

Argemí-Armengol, I., Villalba, D., Ripoll, G., Teixeira, A., \& Álvarez-Rodríguez, J. (August 2019). Credence cues of pork are more important than consumers' food-related lifestyles to boost their purchasing intention. Meat Science, 154, 11-21. https://doi.org/ 10.1016/j.meatsci.2019.04.001.

D'Souza, D. N., Pethick, D. W., Dunshea, F. R., Suster, D., Pluske, J. R. \& Mullan, B. P. (2004). The pattern of fat and lean muscle tissue deposition differs in the different pork primal cuts of female pigs during the finisher growth phase. Livestock Production Science, 91, 1-8.

Duziński, K., Knecht, D., Lisiak, D., \& Janiszewski, P. (2015). Factors affecting the tissues composition of pork belly. Animal, 9(11), 1897-1903.

Eggert, J. M., Grant, A. L., \& Schinckel, A. P. (2007). Factors affecting fat distribution in pork carcasses. The Professional Animal Scientist, 23(1), 42-53.

Fernandes, A., \& Teixeira, A. (Eds.). (2015). Porco Bísaro. Qualidade da carcaça e da carne. Bragança, Portugal: Quinta do Bisaro.

Font-i-Furnols, M., Tous, N., Esteve-Garcia, E., \& Gispert, M. (2012). Do all the consumers accept marbling in the same way? The relationship between eating and visual acceptability of pork with different intramuscular fat content. Meat Science, 91, 448-453.

Franci, O., Pugliese, C., Bozzi, R., Acciaioli, A., \& Parisi, G. (2001). The use of multivariate analysis for evaluating relationships among fat depots in heavy pigs of different genotypes. Meat Science, 58, 259-266.

Franco, D., \& Lorenzo, J. M. (2013). Effect of gender (barrows vs. females) on carcass traits and meat quality of Celta pig reared outdoors. Journal of the Science of Food \& Agriculture, 93, 727-734.

Gispert, M., Oliver, A., Velarde, A., Suarez, P., Pérez, J., \& Font-i-Furnols, M. (2010). Carcass and meat quality characteristics of immunocastrated male, surgically castrated male, entire male and female pigs. Meat Science, 85(4), 664-670.

Gu, Y., Schinckel, A. P., \& Martin, T. G. (1992). Growth, development, and carcass composition in five genotypes of swine. Journal of Animal Science, 70(6), 1719-1729.

Hocquette, J., Gondret, F., Baéza, E., Médale, F., Jurie, C., \& Pethick, D. (2010). Intramuscular fat content in meat-producing animals: Development, genetic and nutritional control, and identification of putative markers. Animal, 4(2), 303-319.

Huxley, J. S. (1932). Problems of relative growth. London: Methuen.

Jones, S. D. M., Richmond, R. J., Price, M. A., \& Berg, R. T. (1980). Effects of breed and sex on the patterns of fat deposition and distribution in swine. Canadian Journal of Animal Science, 60, 223-230.

Kouba, M., Bonneau, M., \& Noblet, J. (1999). Relative development of subcutaneous, intermuscular, and kidney fat in growing pigs with different body compositions. Journal of Animal Science, 77, 622-629.

Kouba, M., \& Sellier, P. (2011). A review of the factors influencing the development of intermuscular adipose tissue in the growing pig. Meat Science, 88, 213-220.

Latorre, M. A., García-Belenguer, E., \& Ariño, L. (2008). The effects of sex and slaughter weight on growth performance and carcass traits of pigs intended for dry-cured ham from Teruel (Spain). Journal of Animal Science, 86(8), 1933-1942.

Latorre, M. A., Lázaro, R., Valencia, D. G., Medel, P., \& Mateos, G. G. (2004). The effects of gender and slaughter weight on the growth performance, carcass traits, and meat quality characteristics of heavy pigs. Journal of Animal Science, 82(2), 526-533.

Latorre, M. A., Olivares, A., Callejo, A., Rey, A. I., Pérez-Ciria, L., López Bote, C. J., \& Daza, A. (30 January 2019). A comparison of female and castrate pigs slaughtered at weights above and below $120 \mathrm{~kg}$ on carcass traits, intramuscular fat and fatty-acid composition of carcasses intended for dry-cured ham and shoulder production. Animal Production Science. https://doi.org/10.1071/AN18267 (AN18267).

Latorre, M. A., Ripoll, G., García-Belenguer, E., \& Ariño, L. (2009). The increase of slaughter weight in gilts as a strategy to optimize the production of Spanish high 
quality dry-cured ham. Journal of Animal Science, 87(4), 1464-1471.

Muth, P. C., Huyen, L. T. T., Markemann, A., \& Valle Zárate, A. (2017). Tailoring slaughter weight of indigenous Vietnamese ban pigs for the requirements of urban high-end niche markets. NJAS - Wageningen Journal of Life Sciences, 80, 27-36.

NRC (2012). Nutrient requirements of swine. National Research Council(11th ed.).

Washington, DC: National Academy Press.

Official Journal of the European Union (2007). Council Regulation (EC) No 510/2006 'Carne de Bísaro Transmontano' or 'Carne de Porco Transmontano' No: EC PT/PDO/005/ 0457/20.04.2005. C89 24.04.200723-25.

Paixão, G., Esteves, A., \& Payan-Carreira, R. (2018). Characterization of a non-industrial pig production system: The case of Bísaro breed. Revista Brasileira de Zootecnia, 47, e20170331.

Ros-Freixedes, R., Reixach, J., Bosch, L., Tor, M., \& Estany, J. (2013). Response to selection for decreased backfat thickness at restrained intramuscular fat content in Duroc pigs. Journal of Animal Science, 91(8), 3514-3521.

Siewerdt, F., Farias, J. V. S., Osório, J. C. S., \& Jacondino, I. F. R. (1994). Allometric growth of primal cuts and tissues in the pig. Ciência Rural, 24(3), 623-627.
Suárez-Belloch, J., Latorre, M. A., \& Guada, J. A. (2016). The effect of protein restriction during the growing period on carcass, meat and fat quality of heavy barrows and gilts. Meat Science, 112, 16-23.

Suarez-Belloch, J., Sanz, M. A., Joy, M., \& Latorre, M. A. (2013). Impact of increasing dietary energy level during the finishing period on growth performance, pork quality and fatty acid profile in heavy pigs. Meat Science, 93, 796-801.

Swatland, H. J. (2004). Meat cuts and muscle foods: An international glossary. Nottingham: Nottingham University Press.

Teixeira, A., \& Rodrigues, S. (2013). Pork meat quality of Preto Alentejano and commercial large white landrace cross. Journal of Integrative Agriculture, 12(11), 1961-1971.

Warriss, P. D. (2004). Meat science. An introductory text. Wallingford, UK: CABI Publishing, $\mathrm{CAB}$ International.

Wood, J. D., Jones, R. C. D., Francombe, M. A., \& Wheleham, O. P. (1986). The effects of fat thickness and sex on pig meat quality with special reference to the problems associated with over-leanness. 2. Laboratory and trained taste panel results. Animal Production, 43, 535-544. 